\title{
Canadian Naval Operational Logistics: Lessons Learned, Lost, and Relearned?
}

\section{Kenneth P. Hansen}

\begin{abstract}
La logistique opérationnelle est un concept principal pour déterminer ce que peut faire une force navale, où elle peut le faire, et pour combien de temps cet effort peut être soutenu, effectivement liant la haute stratégie avec l'action tactique. Les trois éléments d'un système opérationnel de logistique sont le soutien, la fourniture et le support. Bien qu'à peine appréciés, chacun des trois a joué des rôles importants en déterminant les résultats des grands événements dans toute l'histoire des forces navales du Canada. Les capacités navales de soutien, vieillissant aujourd'hui, constituent seulement une version tronquée d'un système logistique entièrement formé. L'avènement de besoins communs de support pour de futurs bâtiments navals de soutien logistique limitera plus encore les capacités déjà réduites de la marine de se mouvoir, de flotter et de combattre.
\end{abstract}

Operational logistics has been described as "what really makes a so-called blue water fleet blue," and "a vital underpinning of a navy's strategy." ${ }^{2}$ It has also been recognized as either "a critical constraining or permissive factor" for the navy in both peacetime and war. ${ }^{3}$ The ability to deploy naval forces and project power at varying distances from home waters is the key discriminating feature in the typology used by the Canadian navy. ${ }^{4}$ This capability is founded principally upon logistical capacity.

Despite being such a critical factor for everything from strategy to tactics, logistics is an under appreciated subject by academics. Jon Sumida called it "a historiographic orphan." There are very few books written on logistics in general and far fewer on the naval aspects of the subject. Most of these are American perspectives that concentrate on operations in the Pacific Ocean during the Second World War. While

1 James L. George, History of Warships: From Ancient Times to the Twenty-first Century (Annapolis, MD: Naval Institute Press, 1998), 213.

2 Ken Booth, Navies and Foreign Policy (New York, NY: Holmes and Meier, 1979), 174.

3 Ibid.

4 Chief of Maritime Staff, Leadmark: The Navy's Strategy for 2020 (Ottawa, ON: Directorate of Maritime Strategy, 2001), 44.

5 Jon Tetsuro Sumida, "British Naval Operational Logistics, 1914-1918," The Journal of Military History vol. 57 (July 1993): 447-480.

The Northern Mariner/le marin du nord, XX No. 4, (October 2010), 361-383 
informative and interesting, to some at least, the scope and scale of superpower operations are difficult to translate into instructive reading for logistical students from medium-power and smaller countries.

The study of military logistical history in Canada is still in its infancy. To date, only one book has been published and it is a branch history of the naval supply corps, ${ }^{6}$ rather than an analysis of the connection between operational planning, logistical capacity and tactical performance. The official history of the Canadian navy in the Second World War is especially disappointing in its treatment of logistical factors. Barely half a paragraph is dedicated to it where the book examines what would have potentially been the most challenging tasks every undertaken by the Canadian navy; the invasion of Japan. Citing a report to the Admiralty by the Royal Navy's liaison officer to Admiral Nimitz's staff, the text records only: "Logistics is the most important aspect of the war at sea in the Pacific."' There is no evidence that this observation was ever noticed, much less acted upon, by Canadian naval planners.

A new book that will include Canadian analysis from the joint and service perspectives is in preparation, but publication is still many months off. The comments presented here will synopsise this author's contribution to the naval-historical dimension of that new collected work. It will also address how the current situation is different from those earlier years and what the new security environment means for the logistical dimensions of Canada's future naval force structure.

The theoretical foundation for this analysis is Ken Booth's triangular depiction of the three roles of the navy: the military, diplomatic and policing (or constabulary) roles. ${ }^{8}$ The Booth Triangle is in wide use and it is a key instrument used in Canadian naval strategy formulation.

The Canadian navy's vision document, Leadmark, makes it clear that the military role is the basis for the navy's continuing existence. Moreover, it sets the focus of the naval culture on combat operations after the end of the Cold War:

The military role appropriately forms the base of the trinity, for the essence of navies is their military character. Actual or latent violence is their purpose. It is a navy's ability to threaten and use force that gives meaning to its other modes of action [sic: roles]. It derives its diplomatic impact from perceptions of its military character. Obviously, it derives its utility in conflicts from its ability to exert brute force successfully. ${ }^{9}$

While a direct military threat to Canada is most unlikely in the foreseeable future, it should not be forgotten. Vigilance always is required...The anticipated increase in

6 Mark B. Watson, Sea Logistics: Keeping the Navy Ready Aye Ready (St. Catharines, ON: Vanwell, 2004).

7 W.A.B. Douglas, Roger Sarty \& Michael Whitby; with Robert H. Caldwell, William Johnston \& William G.P. Rawling, A Blue Water Navy: The Official Operational History of the Royal Canadian Navy in the Second World War, 1943-1945, Volume II Part 2 (St. Catharines, ON: Vanwell Publishing Limited, 2007), 538.

8 Booth, Navies and Foreign Policy, 16.

9 Leadmark, 30. 
expeditionary crisis management missions in the world's littorals likewise will carry the requirement of a navy that is able not only to float and move, but to fight. The need to situate the military role of navies as the foundation of Canada's 2020 fleet is clear. ${ }^{10}$

This assumption, that the basic role for the navy is a military one in all circumstances, should be challenged. In the absence of a direct military threat the constabulary or diplomatic roles should take precedence. There are some grounds within the navy's own vision document for this stance.

Leadmark also states that Canada "has assumed a responsible role in the international community" and "is made more secure by seeing to the resolution of global problems at their source."11 This policy of "engaged internationalism" should also be interpreted as a call for capabilities to support the diplomatic and constabulary roles, since not all global problems can be solved by military means. This point has been missed in the navy's analysis. The common functional element between the employment of the navy in military, diplomatic and constabulary roles is logistical capacity, and it has been the weak link in the Canadian navy's capabilities since its inception. The evident bias within the navy's doctrine arises from the strategic environment at the time its birth and during most of its subsequent history.

The culture of the navy was forged over the period of the first two World Wars and the Cold War. Throughout this period, the presence of a bona fide threat, one which eventually included nuclear weapons, caused the leadership to adhere closely to its professional motto: "Ready, Aye, Ready." The potential for state-on-state conflict demanded high degrees of readiness for combat operations and the maximum levels of technical currency affordable across the board so that whichever unit was at the point of contact would have the best chance for at least survival and, in the best case, for victory. While there were many up-and-down cycles during these eras, the concept that the fleet should be as combat ready and as fighting proficient at possible never varied.

All of the existing major ships in the Canadian navy were built during the period of "The Great Threat Environment." The navy at the end of the Cold War was probably the most technically proficient ever achieved by Canada. This is certainly the opinion of the naval leadership today. The current chief of maritime staff, Vice-Admiral Dean McFadden, repeatedly makes the point that the navy is up to the mark for the military role: "The most combat-effective [navy] we have ever sailed for our shores...a navy that is benchmarked for combat in capabilities and ethos," and "the most combat-effective task group that has ever sailed from our shores." 12 No mention is made of the navy's suitability for the demands of the diplomatic and constabulary roles in the new security environment: the assumption is that if it is combat-effective its capabilities in the other two roles will automatically be satisfactory. Since the end of the Cold War, no major warships or large auxiliary vessels have been approved or built, although two have been attempted and currently rest in a "suspended state of administrative animation." So, the navy of today rests on its laurels from yesterday and the capabilities that made it

10 Leadmark, 95.

11 Leadmark, 11.

12 Dean McFadden, “Ready, Aye, Ready,” Proceedings (December 2009): 35-39. 
"benchmarked for combat."

The major recognized deficiency of the navy is its aging operational sustainment ships - the two oiler-replenishers Preserver and Protecteur-which were once three in number. ${ }^{13}$ Their advanced age and increasing maintenance costs are the cause for only muted concern. While the navy regards their replacement as the top priority, the Joint Support Ship concept will result in two or three ships of reduced sustainment and support capacity traded off for an ability to provide joint supply and movement capabilities. ${ }^{14}$ The dynamic tension caused by the compromise between these capabilities has numerous historical precedents, one of which will be used to set the stage for the prognosis presented later.

It has taken a very long time and many false starts for the Canadian navy to recognize the importance of an operational logistical capacity. It is hard to say whether or not the lessons of the past have been lost or retained, hence the title for this paper. Operational logistics for Canadian naval forces has been of critical importance on a number of occasions but has received scant attention. This was most especially and critically true during the navy's formative experiences in the Battle of the Atlantic - the time when the navy reputedly "came of age." On only one occasion did the navy deploy major forces to a foreign location and attempt to conduct high-intensity combat operations without the benefit of existing logistical facilities. That was the case during the establishment of the Newfoundland Escort Force based at St. John's, Newfoundland. The logistical experiences there spanned all levels of activity, from the strategic to the tactical, and involved all three of the elements of an operational logistics system; supply, support and sustainment. It appears, however, that the lessons available to be learned at that juncture were not internalised by the navy. By the time of planning for Canada's role in the impending invasion of Japan there was no evidence that the naval leadership had understood them. The navy's Cold War experience finally led to the development of a hybrid operational logistics capacity, but its origins stem from a very different set of requirements than those of the Second World War. Understanding this reality is critical to assessing the logistical needs of the navy for the future.

The term "operational logistics" used throughout relates to the support, supply and sustainment of groups of ships operating at sea beyond their normal limits of endurance from their home base of operation or from one provided by another state. Each of these three terms (supply, support and sustainment) relates to a different functional element within the concept of operational logistics. Forays by individual ships do not normally merit dedicated resources and are outside the scope of this analysis. Strategic and tactical issues will only be dealt with when they pertain directly to the provision of the needs of forces operating at sea.

The official American definition of operational logistics relates the concept to the

13 HMCS Provider was decommissioned in 1998.

14 National Defence and Canadian Forces website "Joint Support Ship (JSS)," http://www.forces.gc.ca/aete/jointsupportshipjss-projetdunaviredesoutieninterarmeesnsieng.asp (accessed 10 July 2010). 
provision of resources to deployed joint forces within a regional theatre of operations. It encompasses surface, air and sealift transportation, land facilities and the coordinating arrangements between the elements of this large organizational construct. ${ }^{15}$ The supply of provisions, sustainment of operations and support for organizations within the theatre is viewed as the linkage between strategic-level coordination of production and local forces being given sufficient means to succeed in their tactical endeavours. Before examining the current demand for logistics in the joint context, a single-service naval case will provide a simpler example for use in identifying the functional elements and illustrating their importance.

The Canadian armed services have operated throughout most of the past 100 years in a predominantly single service manner. Despite the almost purely tactical nature of the tasks undertaken by Canada's naval forces, a wealth of unexplored information exists for the study of the operational level. The naval story is unique because ships often trekked across theatre boundaries during their oceanic voyages. The key issue for analysis is the provision of outside resources at the local scene of action to extend the endurance or to enhance the effectiveness of deployed forces. These outside assets constitute an operational resource that higher authority offers to the tactical commander, or upon which the local commander can call when the need arises. Therefore, the logistical means under consideration are not purely tactical resources as they can also be subject to the calls of other nearby local tactical commanders, or can be withdrawn due to higher strategic or operational demands.

The three functional elements of the operational logistics system (supply, support and sustainment) are often confused and the terms are used interchangeably. ${ }^{16}$ It is critical to have them clearly identified. First, the supply element is the means of conveyance for materiel and personnel raised by national acquisition and force generation authorities from the point of production to the point of distribution. It also involves a return loop, which sends all manner of items back for repair or disposal by the national authority. The entire system is commonly referred to in American doctrine as a "pipeline," which involves both ships and aircraft. A large transportation planning organization is intensely involved in the movement of these commodities and this, in turn, hinges upon assumptions made about the volumetric capacities needed for loading, conveyance and unloading. The "pipeline group" backs up the other two functional components of the logistical system. The size and level of activity of the deployed operating groups dictates the number and frequency of the resupply trips and returns. ${ }^{17}$

In the naval context, the "supply chain" is not a continuous connection at all, but a series of packets of various sizes and volumes that move along a flexible route at various times and varying speed. The constrictions on loading and unloading and the constraints on the size, speed and volume of loads are all vitally important considerations

15 Department of the Navy, Naval Logistics (Naval Doctrine Publication 4) (Washington, D.C.: Office of the Chief of Naval Operations, 1995), 7.

16 See, Vice-Admiral George C. Dyer (ret.), USN, Naval Logistics, 2nd ed. (Annapolis, MD: United States Naval Institute Press, 1962), 128-141.

17

Dyer, 137. 
when planning the scope, intensity and duration of naval operations. Operational pauses are usually euphemisms for period of enforced inaction when problems in the supply organization result in demand that cannot be met.

The general goal of the supply chain is to have the right materials arriving in the right quantity at the right place and at the right time. ${ }^{18}$ The supply chain will balance the competing demands of efficiency and effectiveness. Critically urgent small loads needed to maintain effectiveness are most often moved by the most rapid means available, but the cost can be prohibitive; often rated as dollars per ton-mile, depending upon the type of airlift employed. Whatever the movement option, cost and other efficiency penalties will be incurred for the sake of timeliness. For less critical items, economy and efficiency dictate achieving moving maximum quantities within the available volume. The extra time needed for onloading and offloading high volume "tight loads" is acceptable because of the gains in long-term efficiency. Movement by sea provides the option of achieving strategically significant volumes at very low cost; often only a few cents per ton-mile, with the attendant increase in time taken to move the load. However, in terms of total volumes moved over periods of time, generally the discriminating point is between two or three weeks; sealift will decisively outstrip the volumes that can be moved by airlift and will do so at a substantially lower cost. ${ }^{19}$ For some oversized or especially heavy cargoes there is no option for them to be shipped by air.

The second functional element, the support system, attends to routine maintenance and unforecast repairs arising from both normal wear and unusual damage due to weather, accident or battle conditions. As is the case with supply and sustainment, support can entail the establishment of fixed facilities ashore or can be accomplished from mobile facilities afloat. The degree of forward support achieved can be extensive, although more rudimentary means are the norm. ${ }^{20}$ As with the supply function, support requirements are largely dictated by the size of the group deployed, the types of tasks assigned to it and the level of activity experienced. The supply and support elements are commonly treated together as related activities. ${ }^{21}$ For this analysis, it is essential to recognize the conceptual differences between the functional elements in order to understand the truncation that has taken place within institutional organizations.

Third, the sustainment function replaces items consumed during the course of operations. Fuel, food and ammunition are the most commonly discussed commodities, but any other items of supply that are periodically replenished all fall under this category.

18 Captain(N) H.A. House, USN, "Naval Logistics (IV): Maximum Efficiency, Maximum Economy," The Crowsnest vol. 3 no. 8 (June 1951): 26-28.

19 Leadmark provides the following comparative data on transportation costs from a 1998 study by the Directorate of Defence Analysis: $\$ 0.04$ per ton/mile to ship cargo by sea (presumably by merchant cargo ship) versus: $\$ 3.08$ by CC-130 "Hercules" $(+7,600 \%) ; \$ 0.64$ by CC-150 "Polaris" $(+1,500 \%)$; or $\$ 0.41$ by C-17 "Globemaster" $(+925 \%)$ by air.

20 For a description of the development of the USN Support Force in the Second World War, see: Worrall R. Carter, Beans, Bullets and Black Oil: The Story of Fleet Logistics Afloat in the Pacific during World War II, $2^{\text {nd }}$ ed. (Newport, RI: Naval War College Press, 1998).

21 Dyer, 132. 
Sustainment can be carried out while underway or alongside, either point of distribution representing the end of the supply chain. That terminal point of issue will itself be a unit that has replenishment needs due to its own consumption plus the outlays that it provides to clients.

Operational sustainment to naval units while underway requires that the providing unit be designed in a way that facilitates ease of access to its reserves of stores. This arrangement enhances the transfer process but reduces the volumetric capacity of the sustaining unit. Liquid cargoes are the easiest to arrange for efficiency while solids require space for access, handling, delivery and replenishment. The imperative for the sustaining unit is to function in such a way that it only impedes the tactical efficiency of the group to the absolute minimum. Creating a tactical vulnerability due to the need for sustainment is an anathema in a style of warfare that demands the utmost in awareness and reactiveness.

The demarcation between the three functional elements in the operational logistics system has become blurred due to the innovation of combining the three components of the system into a variety of multi-purpose shore facilities and afloat units. 22 It is a standard feature for naval units themselves to incorporate a degree of selfsupport through the development of technical tradesmen among sailors and the inclusion of workshops into ship designs. Storerooms, fuel bunkers and munitions magazines are all built according to estimates of the normal and wartime operating demands of service. Increased endurance through conversion of such spaces as water ballast tanks and engineering spaces to tankage have been used often to enhance fuel capacity. History has innumerable examples of ships being crammed to the deckheads with stores of all sorts to increase the human endurance of the ship. The same can generally not be said of munitions, which require safe stowage that prohibits casual arrangements. The space and resources needed for such logistical features are all tradeoffs in ship design.

The demand that operations by warships causes for operational logistics depends on a host of assumptions that went into their design. Admiral Alfred Mahan wrote that the design of all warships is the result of a compromise: "You cannot have everything. If you attempt it, you will lose everything. On a given tonnage...there cannot be the highest speed and the thickest armor, and the heaviest battery, and the longest coal endurance."23 The implication of this compromise is that all ships will have special abilities best suited to certain purposes. These characteristics are the results of perceived needs that stem from the strategic setting of the era or from the dimly perceptible future. With the choice to focus on these capabilities comes the consequence of having lesser abilities in other areas. This is the natural consequence of the physical limitations within which naval

22 Tim Fish, "Multipurpose Ships: logical solutions for the small navy," Jane's Navy International (December 2009): 12-19.

23 Alfred T. Mahan, Naval Strategy Compared and Contrasted with the Principles and Practice of Military Operations on Land (Boston, 1911), 44, cited in John B. Hattendorf and Wayne P. Hughes, Jr., eds. Mahan on Naval Strategy: Selections from the Writings of Rear Admiral Alfred Thayer Mahan (Annapolis, MD: Naval Institute Press, 1991), xxxi. Emphasis in original text. 
architects must function: ships designed or built during periods of war, or in the lead up to them, will lean towards specialization in one or another type of combat operations, but none will excel in all of them. This means that choices will have to be made in a wide variety of areas. The demand for operational logistics is determined in large part by that process of compromise and its consequences.

As the Canadian navy celebrates its centenary, it is important to remember that nearly 90 of the navy's first 100 years were spent in a high threat environment for stateon-state conflict. A known and recognizable military threat to Canada, to its national interests and to its international standing in the world caused naval planners to prize certain characteristics that suited their vessels to specific types of combat operations and tactical activities. Since Canada was not an aggressor nation, for the most part these combat operations were viewed as defensive in nature. Therefore, the basic plan of operation was local patrols in home waters. That general concept did change considerably, and a defensive posture was the general starting point for fleet structure design and operational planning.

Because of the existence of a recognized threat and the basic mission to protect the homeland, the type of endurance needed to sustain distant and long-duration operations seldom entered into the naval calculus that resulted in Canadian force planning models. ${ }^{24}$ Other factors also played major parts in determining the endurance characteristic of the Canadian navy. Three major ones included: the cultural loyalty of the RCN's leadership to British patterns of short-range designs, a focus on battlefleet operations over the protection of trade, and a Europe-centric focus that emphasised operations in the Atlantic rather than the Pacific Ocean. Canadian warships leading up to the Second World War were typically short-range and low-endurance vessels optimised for limited tactical engagements associated with the battlefleet engagements.

\begin{tabular}{|l|l|l|}
\hline Warship Types & $\begin{array}{l}\text { Battlefleet Engagement } \\
\text { (Low Endurance) }\end{array}$ & $\begin{array}{l}\text { Trade Warfare } \\
\text { (High Endurance) }\end{array}$ \\
\hline Scouts & Fleet Carriers (heavy \& light) & Escort Carriers \\
\hline Main Battle Units & Battleships & Battlecruisers \\
\hline Leaders/Patrollers & Light Cruisers & Heavy Cruisers \\
\hline Screeners/Escorts & Destroyers & Frigates \\
\hline $\begin{array}{l}\text { Flotilla Craft } \\
\text { (Civil designs) }\end{array}$ & $\begin{array}{l}\text { Torpedo Boats } \\
\text { (Corvettes) }\end{array}$ & $\begin{array}{l}\text { Sloops } \\
\text { (Cutters) }\end{array}$ \\
\hline Skirmishers & Fleet Submarines & Trade Attack Submarines \\
\hline
\end{tabular}

Table 1 - General Division of Warship Types by Fleet Function and Endurance.

Canadian naval planners selected destroyers over longer-range cruisers and sloops in order to remain relevant to Royal Navy (RN) battlefleet surface operations, albeit at virtually the lowest level of combat capability. ${ }^{25}$

24 For further development of this line of argument, see: Kenneth Hansen, "The 'Destroyer Myth' in Canadian Naval History," Canadian Naval Review vol. 2, no. 3 (Fall 2006): 5-9.

25 Ibid. Torpedo boats had been dropped from the RN fleet plan by the end of the 1920 s, when 
This lack endurance on the part of the RCN was not viewed as a major disadvantage. The great equalizing effect was first provided by the fleet logistics resources of the RN and, later, by the even greater capacities of the United States Navy (USN). So long as a threat could be identified that could menace Canadian interests, all considerations in the design of warships favoured the enhancement of combat capabilities and the diminution of their other characteristics. Internal spaces were turned to more powerful machinery, longer range weapons, magazines, and sensors, rather than greater fuel capacity, stores or accommodations. The combat logic upon which battles turned demanded awareness, speed of reaction and firepower to provide the greatest chances of success. ${ }^{26}$ As the range and accuracy of weapon systems increased, the imperative to sacrifice all unnecessary attributes for the sake of increased combat efficiency grew stronger.

The first major realization of the endurance shortcomings of the RCN came during the Battle of the Atlantic in 1941. In response to widening German submarine operations, in mid-April 1941 the Admiralty extended convoy escort to 35 degrees West. To accomplish this task, three RN escort groups were moved from the U.K. to Iceland. Their task was to provide continued protection from the point where Western Approaches escorts broke away from a westbound convoy out to the new western limit of close escort. From this point onwards, escort fuel shortages played a major role in the conduct of convoy operations.

The endurance of most British escorts was inadequate for mid-Atlantic convoy work. By May 1941, the spread of German submarine operations further westward made the creation of another escort force necessary to cover the intervening distance between 35 degrees West and the point where Halifax-based escorts could take over protection of inbound convoys and relinquish outbound ones. The result was the establishment on 23 May 1941 of the Newfoundland Escort Force (NEF) based out of St. John's, Newfoundland. ${ }^{27}$ The first seven Canadian corvettes assigned arrived at St. John's on 27 May 1941. HMC ships Chambly, Collingwood, and Orillia departed St. John's on 2 June to join the close escort group for the 57-ship Halifax to Liverpool convoy HX-129. The convoy, which left Halifax on 27 May, was the first to have continuous close escort all the way across the Atlantic. The Canadian ships detached from the convoy and proceeded to Iceland for fuel while a $\mathrm{RN}$ group took up the continuing escort duty to the point where the eastern local escort group was met. The stories of how Canada organized the naval logistics system in a remote and austere location, in what was the RCN's only operational command of the entire war, is a key illustration of how to, and how not to, conduct such matters. The sequence of events causes an examination of the support functional element first, followed by the supply and then the sustainment functions.

RCN fleet plans were being formulated: George, History of Warships, 248.

26 Wayne P. Hughes, Jr., Fleet Tactics and Coastal Combat, (Annapolis, MD: USNI Press, 2000). See especially, Chapter 6, "Evolution of Tactics in the Age of Missile Warfare," 145168.

27 Gilbert Tucker, The Naval Service of Canada: Its Official History, vol. II (Ottawa, ON: King's Printer, 1952), 193. 
The Admiralty reached its decision on the need for a shore base in Newfoundland on 20 May 1941, only seven days before the first Canadian corvettes arrived at St. John's. The initial concept for the new base was a site for running repairs only, accomplished through the use of the existing limited commercial shore facilities augmented by RN auxiliaries. This limited level of effort was termed a "support base" by the USN. The very limited plan was quickly overtaken by events and a more detailed staff estimate of the support capacity required was prepared by a combined British-Canadian committee and submitted to the Admiralty on 23 June 1941. The plans included shore facilities capable of supporting a force of sixty destroyers, corvettes, or sloops without having to resort to afloat support. ${ }^{28}$ This obviously much higher level of effort could only be accomplished by what constituted a "main operating base" under American terminology. This target was never achieved with most facilities cancelled or left uncompleted by war's end.

The RN provided several logistics support ships in early June to enable basic operations from such a primitive site. The submarine depot ship Forth arrived on 14 June and was replaced by the more suitable destroyer tender Greenwich three months later, which then stayed until July 1943. The depot ships and tenders were equipped with workshops and technicians able to effect repairs on most weapons and other systems used by warships of that era. However, the general plan was that each depot ship or tender could comfortably support the basic tactical unit of each type of ship; in the case of destroyers, a flotilla of nine destroyers. The numbers of escorts that suddenly descended upon St. John's quickly overwhelmed the capacity of Greenwich.

The Canadian contribution to the logistical effort was much more limited. The former Great Lakes passenger ship Georgian was acquired for use as an accommodations barge. She was renamed Avalon II, arrived in May 42 and remained until October 1944. Two small tankers were acquired for use as harbour fuelling barges; Mastodon and Moonbeam. ${ }^{29}$ Their arrival and departure dates are not recorded.

The lack of naval logistical capacity at St. John's quickly caused a severe drop in operational effectiveness. The rudimentary support capabilities of the local shipyard and the depot ship were totally inadequate to provide maintenance and repairs for the escort force. Fully one-third of the entire British-Canadian force was normally out of service due to mechanical defects requiring major repair or refit. ${ }^{30}$ By September 1941, the ten Newfoundland Escort Groups, formed from some 60 ships, averaged just four effective ships that normally consisted of one destroyer and three corvettes. ${ }^{31}$

Commentaries by contemporary American observers paint a bleak picture. On 23 October 1941, Captain Deyo, Admiral Bristol's destroyer commander in Iceland, observed the obvious strain on Canadian ships from making too quick convoy cycles:

\footnotetext{
28 Tucker, II: 193-194.

29 The deadweight tonnage for Mastodon was approximately 1,900 tons and for Moonbeam was approximately 900 tons.

30 Douglas, 228.

31 Douglas, 223; Tucker, II: 198.
} 
"They arrive here tired out and the [destroyers] just barely making it ... With winter coming on their problems will be more difficult. They are going to have break downs and ships running out of oil at sea [due to mechanical inefficiency]." ${ }^{32}$ On 20 December 1941, Admiral Bristol wrote to Admiral King and advised him that it was increasingly apparent that the RCN was mostly "a paper strength force" and that their difficulties in maintaining escort groups was primarily due to "the inadequacy of their maintenance ideas and facilities." ${ }^{33}$ The escort operations were being jeopardized by the limitations of the inadequate support arm of the operational logistics systems.

The problem was alleviated mainly through the resources of the USN. The USN deployed the large destroyer tender USS Prairie, which also served as the headquarters for Rear-Admiral Arthur L. Bristol, commander of the Atlantic Support Force (renamed Task Force Four on 10 October 1941 and, finally, Task Force 24 on 13 March 1942). ${ }^{34}$ Additionally, \$13 million was allocated under the First Supplemental National Defense Appropriation Act of 1942 to develop a full operating base at Argentia, Newfoundland. This made the American base a close second to the new naval air station at Barber's Point, Oahu, as the most expensive construction project for the USN during the Second World War. ${ }^{35}$ Work progressed at a brisk pace and the largest part of the project, a 7,000ton floating dry dock, was towed to Argentia and received its first ship on 26 June $1943 .{ }^{36}$ Of Argentia Commander (later Vice-Admiral Sir) Peter Gretton wrote: "[W]e used to say that the bright lights were at St. John's, but Argentia was the place to get repaired." ${ }^{37}$ The attention paid to maintenance and sustainment in USN planning for the base at Argentia produced results that were recognized in the RN, if not the RCN. Beyond problems of support, the Canadian supply chain was also a critical weakness

Fuel at St. John's was the most immediate and persistent problem. Existing oil storage was only 4,500 tons at the Imperial Oil Company tanks farm, which was considered only enough to meet merchant ship bunkering requirements. The most pressing supply need was for fuel and the first ships to arrive were a collection of commercial tankers to serve as station oilers: Teakwood arrived on 29 May 1941 and

32 United States Navy, Administrative History of the U.S. Atlantic Fleet in World War II, Vol. II, Commander Task Force Twenty-Four (Washington, DC: Commander in Chief, United State Atlantic Fleet, 1946), 91.

33 Ibid., 105.

34 Morison, History of United States Naval Operations in World War II, vol. 1 (Boston, MA: Little Brown, 1947), 50-51 n38, 90 n25.

35 Goodhart recorded the total amount expended as $\$ 44,912,927$ and claimed "Argentia was the most expensive of all the overseas American bases built during the war." The Hawaiian Territories were considered overseas possession and not part of the continental United States. Although Argentia was costly, the official records do not substantiate Goodhart's claims. Philip Goodhart, Fifty Ships that Save the World: The Foundation of the Anglo-American Alliance (London, UK: William Heinemann Ltd., 1965), 226-228.

36 Department of the Navy, Building the Navy's Bases in World War II: History of the Bureau of Yards and Docks and the Civil Engineer Corps, 1940-1946, vol. II (Washington, D.C.: United States Government Printing Office, 1947), 38-39, 52.

37 Peter Gretton, Convoy Escort Commander (London, UK: Cassell, 1964), 150. 
departed December 1943; Clam, arrived on 9 June; Empire Salvage $e^{38}$ arrived in May 1942 and replaced Clam, remaining until December 1942; British Honour arrived November 1942 and departed May 1943; and Scottish Musician arrived May 1943 replacing British Honour and departed March 1944. ${ }^{39}$ The stores issuing ship City of Dieppe arrived on 3 June and stayed for a year to provide a supply distribution point. The plan for a naval fuel facility of 13,250 tons capacity was quickly invalidated as, by March 1942, the weekly outlay of naval fuels rose to 5,800 tons. ${ }^{40}$ The original plan for naval fuel tankage was expanded by a further 27,000 tons at the same time that the first of the naval shore fuel tanks was put into operation in September 1942. To bridge the gap between demand and supply, two British auxiliary tankers, Clam and Teakwood, joined HMCS Moonbeam to act as depot oilers.

At Argentia, among the first USN projects completed was a six-tank fuel oil storage farm with a total capacity of approximately 50,000 tons. One of the tanks was used to store 80-octane aviation fuel. Two additional tanks, holding 3,500 tons of 100octane aviation fuel, were added later. ${ }^{41}$ The American move to build a large fuel oil tank farm, one that was 277 percent larger than the first Canadian naval facility, as their first priority shows a markedly more sophisticated understanding of logistical planning than their British and Canadian counterparts.

The Allied fuel emergency of 1942-43 was felt most acutely at St. John's. ${ }^{42}$ Gilbert Tucker recorded two critical facts. First, the supply of fuel oil on the Canadian east coast was seriously jeopardized though enemy action and, second, in December 1942, the urgent need for tankers caused the plan for shore fuel tankage in St. John's to be expanded. ${ }^{43}$ Neither Tucker's nor Douglas' (et. al.) official histories connected fuel oil shortage to poor tactical escort performance by the Newfoundland escort groups. In May 1942, the British auxiliary tanker Empire Salvage arrived, replacing Clam, and Teakwood began a shuttle run to St. John's from either Halifax or Montreal to obtain fuel to replenish both the tanks ashore and the station tanker. Despite these measures, stocks remained low and by late 1942 another crisis situation arose.

The Directorate of Fuels at NSHQ recorded average monthly fuel issues during

38 Often erroneously identified as a salvage ship due to its name, but was actually the former Dutch tanker Papendrecht, captured by the Germans and converted to the oiler Lotheringen, captured in turn by HMS Eagle after the sinking of Bismarck and renamed to indicate its recapture from the enemy rather than its function.

39 The deadweight tonnage (total liquid cargo capacity) for the tankers was: Teakwood, 9,100 tons; Clam, 9,800 tons; Empire Salvage, 10,750 tons; British Honour, 10,300 tons; and Scottish Musician, 9,700 tons. Average $=9,930$ tons. E.C. Talbot-Booth, Merchantships, 1942 (London, UK: Sampson, Low, Marston \& Co., 1942).

40 Tucker, II: 194.

41 Department of the Navy, Building the Navy's Bases in World War II, II: 38-39, 52.

42 For the full story of the persistent oil shortages suffered in the U.K. and Canada, see: D.J. Payton-Smith, Oil: A Study of War-time Policy and Administration (London, UK: HMSO, 1971).

43 Tucker, II: 195. 
the fall of 1942 as 3,500 tons per week or 14,900 tons per month. ${ }^{44}$ This means that the 10,000 tons of fuel in the station tanker plus the 4,500 tons ashore at St. John's was barely adequate to meet the demand for the NEF. The scheduled arrival of 13 additional destroyers, most of which were ex-USN Wickes-class and Clemson-class ships that were known to be notoriously fuel inefficient, was expected to increase demand to 22,300 tons per month $(5,200$ tons per week). Directorate of Fuels data shows that Tucker's figure of 13,250 tons $(89,000$ barrels) in naval storage was actually the combined total of all fuels in both naval and Imperial Oil storage. Therefore, shore storage in naval tanks was really only 8,750 tons (59,000 barrels), representing a little over half a month's supply once the 13 additional destroyers arrived. The new naval tank farm under construction would increase shore capacity to 33,250 tons (223,400 barrels or six weeks' supply). Officers from the Directorate of Fuels urgently pressed local construction authorities for an early completion date and were given assurances that the first tanks would be available for limited use in February 1943. It is not known if this was fully accomplished but the facility did not come into full use until September $1943 .{ }^{45}$

Fuels stored afloat in Empire Salvage (10,750 DWT) augmented limited fuel supplies ashore at St. John's. She raised naval fuel reserves to approximately 19,500 tons (based on the unrealistically optimistic assumption that her entire deadweight represented usable cargo), representing little more than one month's supply at the prevailing rate of usage. Neither the actual nor the forecast consumption estimates included abnormal demands, such as the irregular fuelling of RN or USN warships arriving in St. John's. The removal of Empire Salvage would drop total fuel reserves to 58 percent of a month's supply at the current rate of usage and only 39 percent once the extra destroyers arrived. Just as the Battle of the Atlantic was moving into its most active phase, naval fuel stocks at St. John's reached their most precariously low levels.

Three cargo ships were engaged in a naval fuel shuttle service from Halifax to St. John's: the old, slow, and unreliable coastal tanker Sarnolite (3,000 DWT), plus two RN auxiliary tankers, Teakwood (9,100 tons), and British Honour (10,300 tons). There were also four other small tankers that transported gasoline only. The two large tankers are recorded to have made a total of two return trips from Halifax to St. John's per month. To complicate matters further, the large tankers were prohibited from travelling in the same convoy and arriving in port at the same time, as there was neither the cargohandling facilities nor shore tankage to allow them to unload simultaneously.

A temporary solution was reached by having British Honour perform double duty as both a shuttle tanker and as a depot oiler. Teakwood continued in the shuttle service, unloading twice a month at St. John's. Whenever British Honour became low on fuel, she returned to Halifax to bring in another load. If one of these tankers was sunk or damaged by enemy action, or even delayed by weather, a very critical fuel situation would have developed. Once the new shore tankage became available, both ships were

44 Memorandum, Lt D.W. Overend, RCNVR, SO (Fuels) Operations Division Ottawa, to D.O.D., "Fuel Oil St. John's, Newfoundland," 8 December 1942, RG 24, D-1-b, box 3960, file NSS 1044-12-1, Library and Archives Canada [hereafter, LAC]. 
intended to concentrate on the fuel shuttle service to build up a reserve of fuel.

As the Battle of the Atlantic progressed towards it climax, supplies of naval fuels at St. John's continued to be grievously short. Historian Robert Fisher revealed that by late March 1942, stocks of naval fuels in St. John's had declined to under 3,000 tons, which amounted to only three days' of supply. By late April, all fuels at Halifax totalled only 45,000 tons, which he assessed was the equivalent of only 15 days' supply for forces operating there. ${ }^{46}$ The continued viability of the trans-Atlantic convoy system was in serious jeopardy due to a lack of fuel.

The forecast of higher consumption was realized in the week ending 20 March 1943, when expenditures totalled 5,000 tons. A short respite developed during the next three weeks in March-April when fuel consumption eased to 3,900 tons per week. However, in the week ending 17 April, fuel usage skyrocketed to 7,250 tons and the files record that "panic gripped the Directorate of Fuels." Once again, a respite of sorts occurred over the next four weeks when weekly fuel expenditures dropped to 5,100 tons. For the week ending 22 May, consumption soared again to 6,950 tons. ${ }^{47}$ Although the ten-week average was 5,125 tons, wild swings in weekly consumption caused problems for planners attempting to estimate future requirements. Then, without warning, the fuel consumption situation at St. John's suddenly and dramatically reversed itself, leaving the Directorate of Fuels trying to discover the cause. Over the next eight weeks, average weekly fuel issues at St. John's were 3,225 tons, with a low of only 1,500 tons in the week ending 3 July. Canadian logistics staff officers in Ottawa scrambled to determine the cause and make adjustments to their fuel delivery plans.

The cause of the downturn in fuel outlays at St. John's was the result of the third element of the logistical system, sustainment. From June 1942 onward, the USN forces operating in Task Force 24 began conducting refuelling at sea from commercial tankers in convoy. This ability to refuel escorts at sea from convoy tankers was developed principally by Captain Paul R. Heinemann, USN, Commander of Task Unit 24.1.3 (known as Escort Group A-3 in British and Canadian literature). Captain Heinemann adapted the standard USN abeam refuelling method and trained Canadian and British escort vessels in the practice. He also brought the potential of underway refuelling to the attention of the commander-in-chief, Western Approaches, Admiral Sir Max Horton. Over the strenuous objections of his senior staff, Horton ordered the adoption of this practice by $\mathrm{RN}$ escort groups. ${ }^{48}$

46 Robert C. Fisher, "We'll Get Our Own: Canada and the Oil Shipping Crisis of 1942," The Northern Mariner vol. III, no. 2 (April 1993): 33-39.

47 Memorandum, Lt. (SB) D.W. Overend, RCNVR, SO (Fuels) to Cdr. R.L. Dunsmore, RCNVR, Director of Fuels, “Operations Report \#1," 27 July 1943, File 72/71, Directorate of History and Heritage [hereafter, DHH].

48 Ken Hansen, "Escort Oilers: The Untold Story of the Battle of the Atlantic," in New Interpretations in Naval History: Selected Papers from the Sixteenth Naval History Symposium Held at the United States Naval Academy 10-11 September 2009, Craig C. Felker, ed., (Gainesville, FL: University Press of Florida, forthcoming in Fall 2010), 162186. 
Only the very few RN and RCN ships attached to Task Force 24 and employed in Escort Group A-3 were exposed to American operational logistics techniques. The leadership and inspiration of Captain Paul Heineman in the field of operational logistics is of such vital importance to the ultimate victory in the Atlantic that it far outweighs the tactical contributions of the only active USN escort group. His carefully orchestrated briefing of Admiral Horton at Derby House in December 1942 on the subject, which resulted in Horton's orders to implement the practice throughout RN convoy escort forces in the Atlantic, should rank as one of the most important events in the history of the Battle of the Atlantic. ${ }^{49}$

Once it became possible to refuel escorts at sea, a fundamental rationalization of the Atlantic escort system was effected that improved the tactical efficiency of escorts and shortened the distances travelled by convoys. Larger escort groups obviated the need for evasive routing, which reduced the demand for fuel and raised the cargo hauling efficiency of merchant shipping. Despite all of this, the RCN remained unaware of the benefits of operational logistics and struggled to understand its effects.

A signal was sent from the Admiralty on 28 March 1943 that made fundamental changes to British organization for escort of convoy operations: "It has been decided that tankers fitted with oiling at sea gear for service as escort oilers are to be recognised as forming an integral part of the convoy escort system in the proportion 2 escort oilers to each escort group." ${ }^{50}$ In order to implement this decision, the Admiralty assigned the highest priority over all other work to accomplish four critical tasks: the fitting of fuelling platforms or other type of oiling at sea gear; the maintenance, repairs, or alterations of that gear; repairs to tankers which had been or were being fitted with gear; as well as berthing and discharging of escort oilers. With such high-level support, escort oilers soon became available for service in all trans-Atlantic convoys.

The Admiralty also signalled a major change in operating practices for the escort of convoys. Oilers were stationed well within the convoy, normally in the two columns adjacent to the convoy commodore's flagship, which also included escort carriers when they were present. To facilitate refuelling, the entire convoy would alter course if the planned track proved unsuitable due to conditions of sea and swell. Even the basic definition of an escort group was changed: "The composition of an Escort Group is thus, in effect, the vessels forming the Group plus two Escort Oilers." ${ }^{251}$ Operational logistics had finally become an integrated concept in RN convoy doctrine.

The files of Lieutenant D.W. Overend from the Directorate of Fuels at the Naval

49 The RN resisted the American abeam method of refuelling, preferring instead the "Trough" method for alongside fuel transfer using notoriously fragile $\mathrm{RN}$ bronze metallic hoses, and especially the astern method using inflatable rubber hoses patterned after captured German hoses manufactured in the United States. Neither were as efficient as the American system.

50 Message, Admiralty to CINC CA NWA, 7 June 1943, RG 24, D-1-b, box 3960, file 1044-126, pt. 1, LAC.

51 Memorandum, "Notes for Escort Oiler Supervising Officers, New York and Halifax - Duties and Responsibilities," 22 May 1943, RG 24, D-1-b, box 3960, file 1044-1-26, pt. 1, LAC. Emphasis in original text. 
Service Headquarters in Ottawa provide major insights into the extraordinary fluctuations in fuel consumption at St. John's during the first six months of 1943. During MarchSeptember 1943, only five of 12 escort groups (42 percent) bound for Newfoundland were destined for St. John's. Therefore, St. John's share of the average monthly savings from the 5,580 tons supplied to escort groups by refuelling at sea was 2,350 tons. Adding this amount to the average monthly issue at St. John's of 3,225 tons results in total weekly fuel consumption by RCN escort groups from all sources of 5,575 tons. This amount was actually 8.7 percent higher than the weekly average of 5,125 tons issued at St. John's during the previous 10 -week period that included the spikes of 7,000 tons and more in fuel consumption that had so shocked Directorate of Fuels staff. Although the total of all fuels issued ashore and afloat (5,575 tons) represented only a relatively small increase over the average figure (5,125 tons), all the other fuel-saving factors (direct routing, better weather, improved warships entering service) were also having effect. The net result was that the actual increase in total fuel consumption by Canadian escort groups was certainly higher than eight to nine percent. This increased fuel consumption represented the freedom to employ speed to offensive and defensive tactical advantage. The use of escort oilers not only enhanced the effectiveness of escorts at sea by allowing them to be as aggressive as they desired without concern for fuel supply but also substantially reduced the logistical strain at St. John's.

Aggressive anti-submarine hunting plans, sometimes known as "Swamp Tactics" for the level of surface and air assets assigned to the scene of action, became the norm for Allied anti-submarine groups. Hunting the submarine to the limits of its endurance was made possible by the luxury of unlimited fuel supplies. This form of high-intensity antisubmarine planning and tactics became the pattern for post-war Canadian naval operations, but the linkage to operational sustainment was not clearly understood until long after the war's end.

The story of operational logistics for the Newfoundland Escort Force at St. John's provides insights into all three elements of the system. As bad as the situation was at that time, the navy was fortunate that the forward location was relatively near to the navy's main points of supply, the national industrial base, and the navy's main operating base in Halifax. That would not have been the case had the navy been deployed to participate in Operation Downfall, the invasion of Japan.

The first tentative Canadian planning for participation in the Pacific war began in July 1943. This preliminary effort was in the form of an opinion paper produced by the Director of Plans on what type of ships were required for the Pacific war and for the postwar RCN. ${ }^{52}$ Without proper political guidance on missions or tasks, the Canadian naval staff soon envisioned the contribution of a sizable task force including two cruisers, two escort-carriers (later changed to two larger Colossus-class light fleet carriers), all the Tribal-class destroyers, three Prince armed merchant cruisers (now converted to an auxiliary anti-aircraft cruiser and two landing ships), ten of the old River-class destroyers,

52 Memorandum, Director of Plans to Assistant Chief of Naval Staff, "Appreciation of RCN Ship Requirements for the War Against Japan and for the Post-War Navy," 29 July 1943, file 1650-1, DHH. 
69 frigates, 12 Castle-class corvettes, 12 Algerine-class minesweepers, six to 12 landing ships, and the manning of three escort maintenance ships provided by the RN. ${ }^{53}$ The complete absence of sustainment ships indicated that the RCN assumed that the RN would provide all necessary replenishment, supply and support.

On 13 September 1944, Prime Minister King ordered a radical reduction in the numbers of ships and naval personnel to be committed. The revised RCN force amounted to two cruisers, two light fleet carriers, two auxiliary cruisers, 11 destroyers, 36 frigates, and eight corvettes. Notably absent were the escort maintenance ships for logistical support. It had long been held by the Admiralty that Canadian plans to man maintenance ships should not be progressed at the expense of combatant ships. ${ }^{54}$ The Admiralty was counting on the RCN making up a perceived shortage in anti-aircraft escorts to deal with the threat from enemy land-based aircraft. ${ }^{55}$ When it became clear that Canadian plans to acquire cruisers and fleet aircraft carriers were creating a manpower shortage that would mean the manning of the escort maintenance ships could only be accomplished if eight Castle-class corvettes were deleted from the plan, the Admiralty expressed a clear preference for the Canadians not to man the escort maintenance ships. ${ }^{56}$ "Homogeneous forces" comprised of RN and RCN escorts in composite groups were being planned as late as August 1945. ${ }^{57}$ These inter-staff discussions carried on well into 1945. As always, the Canadian naval staff was taking its planning guidance from the Admiralty in London, not the government in Ottawa.

The RCN's predilection for focusing on combat units and ignoring logistics requirements betrayed their amateur status as planners. It also undermined Canadian government policy. Hennessy maintained that the Canadian fleet deployed to the Central Pacific was intended to be "a largely self contained fighting unit." Mackenzie King expressed the desire for the force to be "wholly and exclusively Canadian, fighting as such but under American command in the same way that the British forces will be fighting not however, as subsidiaries of the British Navy, as Churchill had expressed it, but as a Canadian unit." 58 Without any form of fleet train, the RCN would be obliged to become an effective subsidiary of whatever parent navy would deign to provide support. Wherever the logistics went, so too would the RCN go. Without operational logistics, the Canadian Pacific Fleet might not even have been able to go home.

53 Tucker, II: 99-104, 464-465.

54 Message, NSHQ to CNS, 17 0221Z December 1944, RG 24, D-1-c, vol. 8150, file NSS 1655-6, LAC.

55 Message, CNMO to NSHQ, $92205 Z$ November 1944, RG 24, D-1-c, vol. 8150, file 1655 12, LAC.

56 Message, Admiralty to CINC BPF, 6 1027A January 1945, RG 24, D-1-c, vol. 8150, file NSS 1655-6, LAC.

57 Memorandum, Director of Plans to ACNS, 7 August 1945, RG 24, D-1-c, vol. 8151, file NSS 1655-14, LAC.

58 King Diary, 14 September 1944, cited in Michael A. Hennessy, "The Rise and Fall of a Canadian Maritime Policy, 1939-1965" (PhD thesis, University of New Brunswick, 1995), 128. 
The war's end brought a return to a defensive strategic posture for the navy. Fleets on both coasts were drastically reduced, with the force structure emphasis on large carriers, cruisers and fleet destroyers. Tactically, however, the emphasis remained on a high-intensity anti-submarine concept of operations. The advent of nuclear weapons and the Cold War actually increased the importance of the concept due to the consequences for Canadian cities and citizens should the navy fail. The minutes of a Naval Board meeting on 16 August 1957 identified the need to sustain the highest possible intensity of operations in war as the basis for the requirement of an underway replenishment ship. The basic assumption was that the fleet would take up hunting areas approximately 250 miles from base. At that distance, warships would lose 14 percent of their operating time while in transit to and from base. This lost time could be made up either by the construction of six extra anti-submarine ships, costing $\$ 25$ million each, or three replenishment ships, costing $\$ 15$ million each. Based on such simple math, the naval staff agreed to recommend in principal the construction of three replenishment ships at an approximate cost of $\$ 45.75$ million. $^{59}$

The assumptions behind the recommendation to acquire a sustainment capability made it possible to ignore, for the moment, the need for a supply capability. The replenishment ships would provide the most important commodities, including "fuel, ammunition, naval and victualling stores, and helicopter spares." The short distance offshore would allow for temporary absence of the replenishment ships while they departed to replenish themselves and the warships functioned on their own reserves. The nuclear threat, by the time of the 1959 RCN Defence Plan, included submarines launching missiles and torpedoes with nuclear warheads to attack "the retaliatory capacity of the United States, centres of industry government and population, ${ }^{60}$ and sea lines of communication together with harbour facilities." ${ }^{\prime 61}$ Part four of the plan, Personnel and Logistics, made provisions for stocks of material to be maintained as high as possible due to the assumed high rates of usage in combat operations. The support ships (the escort maintenance vessels Cape Breton and Cape Scott) were to be fully stored and kept "dispersed consistent with operational requirements." The threat of nuclear attack also called for the creation of "repair and maintenance organizations or teams" that could be deployed to places not in the target area. Thus, the support, supply and sustainment elements were devised to work at distances that were less than half the 531 miles from Halifax to St. Johns during the Battle of the Atlantic, when the system so nearly collapsed.

Were all of the lessons learned during the Second World War in the Atlantic about the vital importance of operational logistics to tactical effectiveness lost after the war? During the early part of the Cold War the navy moved to build stockpiles of materials in

59 Minutes of the 19/57 Meeting of the Naval Staff held on 16 August 1957, Canadian Forces College Information Resource Centre collection.

60 Cities targeted by various means included: Halifax, St. John, Quebec City, Montreal, Ottawa, Toronto, Hamilton, Niagara Falls, Windsor, Winnipeg, Edmonton, Vancouver and Victoria.

61 RCN Defence Plan CBCN 6904(59), RG 24, accession 83-4/167, vol. 11,147, file 1400-1, pt. 1, pp. 7-8, LAC. 
"safe locations," created a mobile support capacity with two escort maintenance ships, and started plans to build a mobile sustainment capability. The geostatic environment caused the navy to focus first on local defence and to assume that they would be able to function at longer ranges with the support of allied navies if the need arose. The operational logistics system shrank at first to two elements (sustainment and support) and then to one element (sustainment) when the escort maintenance ships were taken out of active service. The notion of maximum six-month rotations for deployment on operations eliminated the need for mobile supply and support, while the limited sustainment capability could meet the demands of very irregular group deployments. Fortunately, the inherent flexibility of the group concept and of the individual warships themselves provided the necessary capacity to meet the demand.

The fuel capacity characteristics of Canadian warships over the past 100 years show that the original trend of relying on low endurance warships persisted until the very latest stages of the Cold War.

\begin{tabular}{|l|l|l|l|l|l|l|l|}
\hline Class & Type & Tonnage & Length & Bunkerage & Fuel/Ton & Fuel/Foot & Endurance \\
\hline Thornycroft S & DD & 905 & 276 & 300 & $.33 / 1$ & $1.09 / 1$ & $2,300 @ 10$ \\
\hline A-class & DD & 1,320 & 322 & 380 & $.29 / 1$ & $1.18 / 1$ & $5,040 @ 10$ \\
\hline C-class & DD & 1,375 & 329 & 473 & $.34 / 1$ & $1.44 / 1$ & $5,775 @ 10$ \\
\hline Bangor & MS & 670 & 180 & 160 & $.24 / 1$ & $.89 / 1$ & $2,800 @ 10$ \\
\hline Algerine & MS & 990 & 225 & 260 & $.26 / 1$ & $1.02 / 1$ & $5,000 @ 10$ \\
\hline Flower & CVT & 940 & 205 & 230 & $.24 / 1$ & $1.12 / 1$ & $3,450 @ 12$ \\
\hline IE Flower & CVT & 976 & 208 & 440 & $.45 / 1$ & $2.12 / 1$ & $4,830 @ 15$ \\
\hline Castle & CVT & 1,010 & 252 & 480 & $.48 / 1$ & $1.90 / 1$ & $9,400 @ 10$ \\
\hline River & FF & 1,570 & 301 & 646 & $.41 / 1$ & $2.15 / 1$ & $7,500 @ 15$ \\
\hline Tribal & DD & 1,927 & 377 & 520 & $.27 / 1$ & $1.38 / 1$ & $5,700 @ 15$ \\
\hline Valentine & DD & 1,710 & 363 & 615 & $.36 / 1$ & $1.69 / 1$ & $6,680 @ 20$ \\
\hline St. Laurent & DE & 2,860 & 366 & 455 & $.16 / 1$ & $1.24 / 1$ & $4,570 @ 14$ \\
\hline Halifax & FFH & 4,750 & 442 & 460 & $.10 / 1$ & $1.04 / 1$ & $7,100 @ 15$ \\
\hline
\end{tabular}

Table 2 - Fuel Capacity of Canadian Surface Warships Under 450 Feet and 5,000 tons.

The ships built during the fuel and endurance crisis phase of the war (identified by the inset box in the table) show a remarkable increase in fuel capacity, whether compared to their displacement or length. The average fuel capacity of all types in Table 2 is .23 tons of fuel per ton of displacement, or 1.21 tons of fuel per foot of length. The average fuel capacity for the high endurance escorts built during the war are .45 tons of fuel per ton of displacement, or 2.07 tons of fuel per foot of length. These figures indicate an extraordinary 95.6 percent increase in fuel capacity per ton of displacement, or an equally impressive 71.1 percent increase per foot of length. 
However, once the fuel crisis was over, the naval predilection for compromises in design to emphasize combat capability over logistical capacity took hold once again. The very low fuel capacity of the St. Laurent-class, and their derivatives which had comparable capacities, resulted in endurance that was actually significantly lower than many of the warships that proved to be so deficient in this regard during the war. Only the advent of more efficient combined diesel-gas turbine propulsion technologies allows the Halifax-class frigates to achieve higher endurance on a proportionally smaller fuel load. When the circumstances dictate that speed will be required, the frigates will have to resort to their high-speed turbines and their endurance will drop substantially. The low endurance of Canadian naval vessels and the abandonment of the concept of local defensive operations as the basis for plans of action do two things. First, they underscore the absolutely critical need for replenishment ships in sufficient numbers; and second, they show the types of ships that have been produced by the process of compromise that existed during the period of "The Great Threat Environment."

The era of threat-based planning is over. The military role of the navy does not envision defensive high intensity operations close to the homeland as there is generally accepted to be no direct military threat to the homeland. Globalization and the need to keep the economic system stable has reduced the likelihood of state-on-state warfare. ${ }^{62}$ The concept of engaged internationalism means that Canada wishes to participate in operations to alleviate suffering, uphold the rule of law and promote human rights in the "four corners" of the globe. Yet, the Canadian navy has been left with the notion that a single-armed operational logistics system originally designed for operations just off the Canadian coast is appropriate for its fleet of limited endurance ships. Worse, the three replenishment ships once in the fleet now number only two, and they are in a very aged and maintenance-intensive state. Worse still is the notion that the next generation of sustainment ships will be a joint asset that can act in a number of support roles for the other services at the same time. The potential for a conflict over priorities is bound to arise. Whose priorities are liable to take precedence?

One source of guidance comes from Elinor Sloan, who analysed force structure requirements in the new security environment, but mainly from the perspective of the land force. Her basic deduction is that, for stabilization and reconstruction operations, the tradition ratio between combat troops and combat support/combat service support troops in the Canadian army's brigade structure should be altered from 3:1 to 1:1. She is of the opinion that the critical deficiency of the army for relevance in contemporary operations is in logistical support. ${ }^{63}$ Can the navy be any different?

Sloan does not make the same specific recommendations for the Canadian navy of the type she makes for the army. However, the current force ratio between combat ships and what would pass for combat support ships (not counting the Kingston-class

62 Chief of Force Development, The Future Security Environment 2008 - 2030: Part 1, Current and Emerging Trends (Ottawa, ON: 17 Wing Publishing Office, 2009), 3-5. The section on "Military and Security Trends" has been relegated to the last third of the book.

63 Elinor Sloan, Security and Defence in the Terrorist Era: Canada and North America, (Montreal and Kingston: McGill-Queen's University Press, 2005), 129-131. 
mine warfare ships) is currently 19:2. Even including the Kingston-class ships with the support portion of the fleet would only raise the ratio to $19: 14$, should they qualify for the support categorization, which they do not. What would a fleet look like that was evenly balanced on a 1:1:1 ratio between combat operations, constabulary operations, and diplomatic operations?

The first step should be to dispense with the bias toward combat capabilities in the design of warships for the fleet. All ships that could conceivably be deployed outside of Canadian waters should have enhanced stores capacities for achieving the highest endurance possible. Beyond this, reserve capacity should also be included in major and minor warship designs to facilitate supporting other government departments and nongovernmental agencies. ${ }^{64}$ Plans to reduce the size and capacity of the Arctic and Offshore Patrol Ships as an economy measure are particularly short-sighted in this regard. The demands upon the support, sustainment and supply elements of the operational logistics system can be reduced substantially by making adequate provision for the first users of the naval capabilities.

The second step would be to recognize the current limitations of the sustainment element of the operational logistics system. Today's replenishment ships were the product of an operational concept that no longer exists. Tasks in any of the three naval roles could require the deployment of forces to any of the furthest reaches of the planet. While the replenishment ships have demonstrated their flexibility on numerous occasions, they are limited in capacity by design. The demand for operational sustainment increases dramatically with the distance, size of forces involved and the tempo of the operations undertaken. As shown in the case study of the NEF, a relatively small increase in the resources available to the operational commander can make an extraordinary difference in the options and the effectiveness of the force. The liberty to use speed, whether for responsiveness or elusiveness, can make the difference between success and failure, between life and death.

The third step must be to recognize that joint demands could remove what the navy views as essential service-specific logistical needs at a critical juncture. It will be grossly inadequate to plan for multi-role ships that can meet only one service's demands while those of the other services go unsatisfied. Multi-purpose designs are acceptable so long as their flexibility allows both rapid conversion from one role to another, and the numbers provided allow for simultaneous tasking to different missions. Richard Gimblett suggested a "transformational fleet" of eight upgraded frigates, ten multi-role support vessels, four submarines and twelve coastal patrol craft. ${ }^{65}$ This idea does not seem so out-of-place once the combat bias of the past is dispensed with and a clean-slate approach to future requirements is adopted.

Recent operations off the coast of Haiti illustrated the need for responsiveness

64 These capacities can include storage for unique equipments, hotel services, spaces for planning and work activities, and the commodities needed to sustain their operations, which can include communications capabilities of a wide variety of types.

65 Richrd H. Gimblett, "A 'Transformational' Fleet for Canada in The $21^{\text {st }}$ Century," Maritime Affairs (Spring/Summer 2000): 42-46. 
and the ability to adjust the volumetric capacity of the supply system to the demand. Patrick Stewart commented favourably on the Canadian navy's abilities with respect to the former but found that their logistical capacity was "positively puny." ${ }^{66}$ Images of Canadian sailors armed with hand tools striding into devastated areas might have been heart warming for the viewers and emotionally rewarding for the participants, but it was largely ineffective. A society in ruins with hundreds of thousands dead and many more homeless need much more than small tactical teams on foot and equipped with hand tools. The new security environment requires that the old design compromises be dropped in favour of a more generalized approach to force planning and capability design.

The experiences of the Canadian navy during Operation Hestia have cast a new light on the need for logistical capacity as a central design criterion for all future Canadian naval vessels. "Volumetrics" is an important dimension of naval science that has yet to receive appropriate attention in Canada. Future missions will almost certainly demand distant operations in any one of the three roles of the navy. The enormous size of the Canadian maritime seascape means that even a domestic mission could demand the requirement to operate at ranges far in excess of anything planned for in the past 100 years of the navy. Whether a domestic or foreign operation, be it military, diplomatic or constabulary, the new security environment will put a premium on an effective operational logistics system that is able to sustain, support and supply both the navy and its sister services, plus the various branches of the federal government, in addition to whatever other non-governmental agencies may be partnered in a coalition effort to achieve mission success. The logistical component is the unifying dimension of all three roles of the navy. Improvements in logistical capacity will enhance all service, government and allied operations.

Two of the key deductions about the importance of logistics during the Second World War to the U.S. Navy are worth considering in the Canadian context. One was that "logistics is part of the exercise of naval command: the naval commander must be indoctrinated in the problems of providing as well as of making use of the means of warfare. ${ }^{97}$ In the age of officer specialization, which is another product of efficiency approaches to threat-based planning, there are no simple solutions to the myriad problems related to supply and demand. Leaders must recognize the interplay between strategic, operational and tactical logistical factors that can affect operational effectiveness. Without this ability at all levels of command, the lack of simple commodities can have crippling consequences. This was the Canadian experience during the Second World War in the Battle of the Atlantic, although it is not generally recognized.

The outcome of the second deduction is that in the U. S. Navy "Logistics has also been included in the curriculum at various levels of naval officer training from the Naval Academy at Annapolis to the War College, and for academic purpose there is now a

66 Patrick Stewart, "How Shipshape are We?" CBC News, 10 February 2010, http:// www.cbc.ca/canada/story/2010/02/10/f-vp-stewart.html (accessed 10 March 2010).

67 Ballantine, 295. 
wealth of precept and experience." ${ }^{68}$ This is not the case in Canada. Logistics is not taught in any depth at any level of professional instruction. With the demise of the Maritime Component Program at the Canadian Forces College, there is no longer any service course that teaches the specifics of naval operational logistics. Naval officers, whether operators or logisticians, cannot acquire the professional acumen needed to participate effectively in either single-service or joint discussions about logistics. This deficiency is as potentially dangerous now in any of the three naval roles as it was during the operations of the NEF during the Second World War.

The current Canadian conception of naval operational logistics stems from its history during the Second World War and the Cold War. Canada's specialized naval forces led to a truncated version of a complete operational logistics system. With the end of the period of threat-based planning, a more compete operational logistics system is required to enable a truly flexible and broadly useful Canadian navy.

The conceptual test of this flexibility will be the ease with which the Booth's Triangle can be rolled off of the military side and onto one of the other two, whether it be the diplomatic or the constabulary side. In an era where there is no direct military threat to the state, it is appropriate that the navy should be effectively and efficiently employable on diplomatic or constabulary missions. One of the key limitations of the Canadian navy in this regard is its limited logistical capacity. The lessons on the logistical limitations in the military role are there to be relearned by anyone who has the interest and the opportunity to study them. It takes only a little imagination to think of the flexibility and utility that improved logistical capacity will add in the increasingly important diplomatic and constabulary roles of the navy in the new security environment of the twenty-first century.

68 Ibid., 296. 


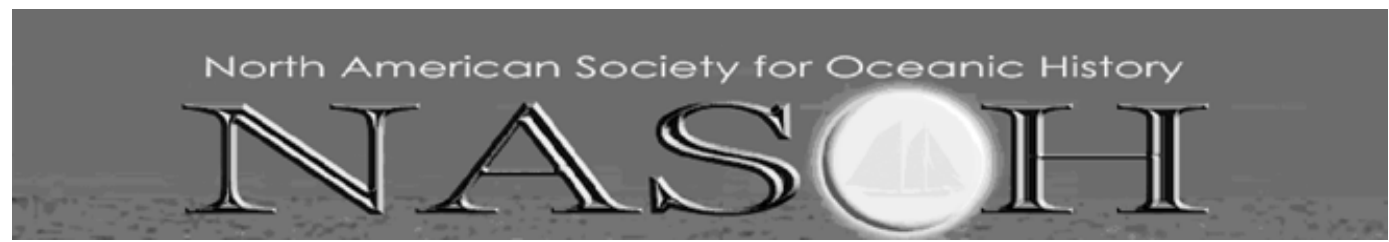

Annual NASOH conference 2011 at Old Dominion University in Norfolk, VA May $12^{\text {th }}-14^{\text {th }} / \mathbf{1 5}^{\text {th }} 2011$

MARITIME HISTORY RESEARCH AT THE BEGINNING OF THE 21ST CENTURY

\section{Call for Papers}

During recent decades maritime history has become far more diverse than ever before. New sub-disciplines of maritime history have developed, traditional topics have been examined from new perspectives, and inter-disciplinary research has become more a standard than an exception. National maritime history research has been embedded into international contexts and global cooperation is a standard for most maritime historians.

The annual NASOH conference 2011 to be hosted by Old Dominion University in Norfolk, VA aims to provide an overview on what is going on in maritime history at the beginning of the $21^{\text {st }}$ century. It aims to stimulate discussion on the development of the discipline as a whole in both a national and global context. Panels will address such questions as: To what degree have maritime historians understood the challenges of the $21^{\text {st }}$ century? In what ways can they contribute to the solution of global problems in the marine realm? What is the relationship of maritime history to new historical subdisciplines such as environmental or Atlantic-world history? Does traditional maritime history still make sense? What's the role of specialized museums and archives for future maritime history?

Proposals for panels of up to four speakers as well as proposals for individual papers addressing the state of the art of maritime history as well as new directions in maritime history research should be submitted prior Jan. $31^{\text {st }} 2011$ to the conference organizers via e-mail (iheidbri@odu.edu). Each proposal for a complete panel should include the title of the proposed session as well as a brief abstract of the session (200 words), the contact details for the organizer of the session and title, abstract (500 words) name and contact details for the individual papers of the proposed panel. Proposals for individual papers should include title, abstract (500 words) name and contact details. Please submit all proposals in one of the following file formats: pdf, doc or $\mathrm{rtf}$ (please no docx-files).

\author{
Dr. Ingo Heidbrink \\ Professor of History-Graduate Program Director- \\ Dept. of History \\ 8046 Batten Arts and Letters Building \\ Old Dominion University \\ Norfolk, VA 23529
}

\author{
tel. $757-683-3656$ or -3949 \\ fax. 757-683-5644 \\ email: iheidbri@odu.edu \\ Skype: ingo.heidbrink
}

